\title{
The Role of Strategic Cost Management in Marketing Decisions: A Case Evidence of Brand Acquisition Assessment
}

\author{
Richard Kristoffer S. Manapat $^{\mathrm{a}}$, V. G. Sridharan ${ }^{\mathrm{b}}$ \\ anstitute of Certified Management Accountants, Australia, and \\ Philippine Institute of Certified Public Accountants, Philippine \\ ${ }^{\mathrm{b}}$ Adelaide Business School, The University of Adelaide, Australia
}

\begin{abstract}
While the role of strategic cost management (SCM) is heralded to pervade through all the links in a firm's value-chain (Anderson, 2006; Shank \& Govindarajan, 2004) the specific role of SCM in relation to a firm's marketing function has thus far been limited to a few areas such as product pricing and analysing customer profitability through activitybased cost allocations (Datar \& Rajan, 2018; Foster \& Gupta, 1994; Van Raaij, 2005). This paper presents a case study to show how SCM concepts can be extended to evaluate brand acquisition by a large organisation. Using shareholder value analysis for pricing the brand and combining with financial statement analysis and strategic positioning models such as Porter's five forces and SWOT, this paper conducts an assessment in order to offer recommendations for a multi-billion peso investment of a large Philippine-based processed foods company seeking to acquire a new brand.
\end{abstract}

Keywords: Brand; Shareholder Value Analysis; Strategic Cost Management

\section{Introduction}

The role of strategic cost management (SCM) in assessing the benefits to the different links (e.g., design, purchases, manufacturing, and marketing) in the value-chain of an organisation is entrenched in the cost management literature (Anderson, 2006; Shank \& Govindarajan, 2004). However, the roles relating to how SCM benefits the marketing function has thus far been limited to offering pricing methods and examining the 
profitability provided by different customer groups (Datar \& Rajan, 2018; Foster \& Gupta, 1994). This paper extends the SCM techniques to a different marketing activity, brand acquisition ${ }^{1}$, to conduct an assessment and make recommendations to the senior management.

Over the past few years, brand acquisitions have emerged as a viable expansion strategy for rapid business growth (Sinclair \& Keller, 2017). Motivations for acquiring brands include the economies of scale it generates, as well as synergistic effects in administrative, sales, market share and corporate reputation (Balmer \& Greyser, 2003). Despite its increasing popularity, barring a few studies (e.g., Guilding, Cravens \& Tayles, 2000), there is surprisingly little in the literature relating to the intervention of SCM in assessing brand values. This dichotomy (between the popularity of brand acquisition concept and the limited SCM applications in the concept) offers considerable opportunities for further research. A comprehensive brand value assessment has significant practical and policy prescriptive implications (Basu, 2006). Our paper is a small attempt in filling this gap.

The remainder of the paper is structured as follows. Section 2 provides the background of the case study within which the author had a participative role in conducting the assessment of the brand value. The section ends with a statement of the research problem. Section 3 presents the diverse brand-related data including product development, supply sources, marketing, management information system and financial summary. Section 4 outlines the conceptual SCM framework that is used to conduct the analyses. Section 5 describes the analyses and presents the findings. Section 6 concludes.

\section{Background and Research Problem}

Samsan Food Inc. ${ }^{2}$ (SFI) is one of Philippine's largest food companies that aggressively seeks to acquire competitive brands apart from improving its own brands. SFI's core business is in manufacturing, marketing, and distribution of protein-rich poultry products. In a span of 80 years, SFI has built 20 in-house brands and acquired eight other

\footnotetext{
${ }^{1}$ In theory, analysis of brand acquisitions are alternatively subsumed under mergers and acquisitions (M\&A) literature (Bahadir, Bharadwaj, \& Srivastava, 2008; Basu, 2006; Guzmán et al., 2012)

${ }^{2}$ The names of both acquiring and acquiree companies along with their brands have been concealed to protect the privacy of the entities.
} 
businesses, which have become immensely popular in the market almost becoming 'household' names. SFI has seven manufacturing facilities across the country, strategically located adjacent to supply sources.

In 2017, SFI received an offer to acquire the brand Good Boy, the market leader in processed cheese, from IN-JAE Corporation (IN-JAE). Upon review of its portfolio, IN-JAE decided to shift its focus to its core category of wholefoods and spin off the Good Boy brand to SFI, which has more product alignment. IN-JAE seeks a 5 billion pesos valuation for the Good Boy brand as well as its manufacturing equipment.

The CEO of SFI handed over the project of assessing this offer author, who in turn, obtained a participatory role in conducting this case analysis. The project execution encompassed end-to-end analysis of both strategic and financial viability, thus culminating in a recommendation. The research problem thus was: 'Should SFI acquire the Good Boy brand at 5 billion pesos?'

This research question is analysed using two different lenses Strategic and Financial:

\section{Strategic}

a. Is Good Boy a valuable brand to acquire?

b. Is this acquisition aligned with SFI's strategy?

\section{Financial}

a. What is the financial health of the Good Boy brand?

b. What is the valuation and the justifiable acquisition price for the brand? 


\section{Case Data}

This section provides an overview of the case data relating to the product, market, logistics and supply sources, and financial position.

\subsection{Product Overview}

Good Boy brand entered the Philippine market in 1986 with a oneproduct strategy through the launch of its iconic sliced cheese. Today, Good Boy maintains an expanded portfolio that includes cheese spreads and cheese dips. Table 1 highlights these details.

Table 1. Historical Sales Per Product

\begin{tabular}{lllllll} 
Product & $\mathbf{2 0 1 4}$ & \multicolumn{3}{c}{2015} & \multicolumn{2}{c}{2016} \\
& Mil. $\boldsymbol{P}$ & \% Share & Mil. $\boldsymbol{P}$ & \% Share & Mil. $\boldsymbol{P}$ & \% Share \\
\hline Sliced Cheese & 2,134 & $67 \%$ & 2,347 & $67 \%$ & 2,653 & $68 \%$ \\
Cheese Spread & 300 & $9 \%$ & 315 & $9 \%$ & 334 & $9 \%$ \\
Cheese Dips & 752 & $24 \%$ & 842 & $24 \%$ & 926 & $23 \%$ \\
\hline Total & 3,186 & $100 \%$ & 3,504 & $100 \%$ & 3,913 & $100 \%$ \\
\hline
\end{tabular}

\subsection{Product Development}

All recipe and bill of materials are owned by IN-JAE and are proposed to be transferred to SFI after successful acquisition. All products are produced in the plant of IN-JAE in Pasig, Philippines.

Product development is mainly done by IN-JAE's research and development (R\&D) group in coordination with the Marketing Department. Generally, Marketing gathers the insight from the consumers, comes up with the ideal new variant or product, and works with $R \& D$ for the formulation. This entire process takes approximately six to twelve months. 


\subsection{Marketing Program}

The Good Boy brand has been on the market for over 30 years and, throughout its history, the brand has been subject to various marketing campaigns that cater to its target markets. Its campaigns range from highlighting health benefits such as Calcium, Vitamin A, and Protein, besides promoting its delicious taste or its versatility in application to different dishes.

In 2016, the advertising and promotion expense of the Good Boy brand reached 438 million pesos or $11 \%$ of Sales (see Table 2). During this year, advertising and promotion stood out to be the largest expense of the Good Boy brand next only to the product cost. Presumably, this cost was needed to steadily increase the sales revenues over the past three years.

Table 2. Advertising and Promotion (A \& P) Support in 2016

\begin{tabular}{llll} 
Product & Sales (Mil. $\boldsymbol{P})$ & $\boldsymbol{A} \& \boldsymbol{P}$ & \% of Sales \\
\hline Sliced Cheese & 2,653 & 323 & $12 \%$ \\
Cheese Spread & 334 & 15 & $4 \%$ \\
Cheese Dips & 926 & 100 & $11 \%$ \\
\hline Total & 3,913 & 438 & $11 \%$ \\
\hline
\end{tabular}

\subsection{Sales and Distribution}

The Good Boy brand is sold directly to more than 400 accounts nationwide. It is available in all supermarkets and groceries. It is also available in downline stores such as sari-sari stores (mom-and-pop stores), mini groceries, and public market stalls.

In terms of sales channels, Modern Trade (MT) and General Trade (GT) account for $55 \%$ and $45 \%$ of the business, respectively. The top 10 MT and GT stores account for $78 \%$ of sales and are considered to be the brand's pareto accounts. Table 3 presents the breakdown of customers in the two types of channels. 
Management Accounting Frontiers 3 (2020) 5 - 24

Table 3. Breakdown of Customers in Sales Channels

\begin{tabular}{|c|c|c|c|c|}
\hline Channel & Customer & Sales (Mil. P) & \% Share & Rank \\
\hline \multirow[t]{7}{*}{ Modern Trade } & Drake Store & 743 & $19 \%$ & 1 \\
\hline & Only One Mart & 548 & $14 \%$ & 2 \\
\hline & Shop Mart Inc. & 196 & $5 \%$ & 6 \\
\hline & Lucas Store & 168 & $4 \%$ & 7 \\
\hline & Lia Mart & 78 & $2 \%$ & 9 \\
\hline & Others & 419 & $11 \%$ & \\
\hline & Sub-Total & 2,152 & $55 \%$ & \\
\hline \multirow[t]{7}{*}{ General Trade } & Mirel Distribution Group & 509 & $13 \%$ & 3 \\
\hline & Gold Wholesales Inc. & 352 & $9 \%$ & 4 \\
\hline & Medusa Merchandise & 293 & $7 \%$ & 5 \\
\hline & Kapihan Tindahan ATBP & 117 & $3 \%$ & 8 \\
\hline & Ethan Corp & 59 & $2 \%$ & 10 \\
\hline & Others & 431 & $11 \%$ & \\
\hline & Sub-Total & 1,761 & $45 \%$ & \\
\hline Total & & 3,912 & $100 \%$ & \\
\hline
\end{tabular}

\subsection{Management Information Systems}

SFI uses Epicor as its ERP Tool and Sandbox Planning Analytics as its Financial Planning Tool. The historical data of the brand coming from IN-JAE will be provided to the buyer in order to come up with proper financial model, sales projections and forecasts, and distribution assumptions.

IN-JAE uses SAP software as their enterprise resource planning (ERP) Tool. One may argue that since this transaction relates to brand acquisition, the system being used by the selling company is not relevant. 
Note however that the historical data arising as SAP outputs are required to be re-formatted or customised to fit into SFI's own ERP tool namely, Epicor.

\subsection{Supply Information}

\subsubsection{Sourcing}

The main raw materials of Good Boy branded products are milk, cultures, and rennet. These are sourced from different suppliers across the globe to ensure availability of supply at all times, proper price control, and efficient ordering process.

\subsubsection{Production}

IN-JAE is currently producing these products at its plant in Pasig City, Philippines. If the acquisition were to take place, the equipment from the IN-JAE plant will need to be transferred to SFI's idle plant in Cavite, Philippines. This will enable SFI to bring synergies to its operations by putting the Good Boy's plant close to its poultry plant.

\subsubsection{Logistics}

SFI has three primary warehouses and 10 sub-distribution centres across the Philippines. It also contracts various trucking and shipping companies to deliver its goods. Good Boy's products will ride on SFI's existing massive distribution structure. 


\subsection{Financial Summary}

The three-year historical income statement as shown in Table 4 was provided by IN-JAE. It will be discussed in detail in Section 5 .

Table 4. Comparative Income Statement from 2014 to 2016

\begin{tabular}{|c|c|c|c|}
\hline & $2014($ Mil. P) & $2015($ Mil. $P)$ & $2016($ Mil. $P$ ) \\
\hline Revenue & 3,186 & 3,504 & 3,913 \\
\hline Cost of Goods Sold & 1,593 & 1,647 & 1,879 \\
\hline Gross Profit & 1,593 & 1,857 & 2,034 \\
\hline Gross Profit Margin & $50 \%$ & $53 \%$ & $52 \%$ \\
\hline Marketing Expenses & 414 & 350 & 438 \\
\hline Selling Expenses & 159 & 210 & 254 \\
\hline Distribution Expenses & 127 & 158 & 168 \\
\hline Administrative Expenses & 96 & 105 & 117 \\
\hline Total Operating Expenses & 796 & 823 & 977 \\
\hline Net Profit Before Tax & 797 & 1,034 & 1,057 \\
\hline Tax Expense & 239 & 310 & 317 \\
\hline Net Profit After Tax & 558 & 724 & 740 \\
\hline Depreciation and Amortisation & 80 & 80 & 80 \\
\hline EBITDA & 638 & 804 & 820 \\
\hline
\end{tabular}

\section{Conceptual Framework}

This section describes the conceptual framework that combines models for evaluating strategic position, environment, financial health and fair price and expected returns. 


\subsection{Strategic Position: Porter's Five-Forces Analysis}

This model seeks to identify and examine the competitive forces that influence an industry and helps channelise a firm's strategic positioning (Porter, 2008). Note that Porter's model can also be applied to even a segment within an industry such as the specific product market in SFI's case study.

\subsection{Environmental Scanning: SWOT Analysis}

This model identifies the relative strengths, weaknesses, opportunities, and threats that prevail for a specific firm in relation to other firms and the industry. The analysis highlights how a firm can benefit from its strengths and capitalise on the available opportunities while managing the weaknesses and threats.

\subsection{Financial Health: Financial Statement Analysis}

This analysis examines growth in revenues, gross margins, and net margins and the control of operating expenses of the Good Boy brand from out of the data collected from IN-JAE. Further, the data are collated along with SFI's current performance in order to verify how the brand acquisition is likely to add further value.

\subsection{Brand Value and Fair Price: Shareholder Value Analysis}

This analysis involves a complementary examination of some strategic and financial models that help assess the brand value and fair price. In the first step, shareholder value analysis (also called 'strategic value analysis) comprises identifying free cash flows (which is earnings before interest, tax, depreciation and amortisation (EBITDA) minus working capital) and adding it with the terminal value (computed as a multiple of price-earnings) of the brand. In the second step, this total value is discounted at a specific rate relevant to the firm (weighted average cost of capital) in order to arrive at the final shareholder value. 


\section{Analysis of the Data}

\subsection{Porter's Five-Forces Model}

\section{Suppliers}

- Multiple sources of milk and rennet from US, China and Europe

- $\quad$ Stable supply and price

\section{Potential Entrants}

- Creation of me-too products from other poultry companies

- Entrance of global Chinese brands

Internal Rivalry

- Low market rivalry due to Good Boy's dominance of the market

- In a good position to further build and grow the business by capitalising the brand and benefiting from synergies across its supply chain

\section{Buyers}

- Dominate the market with $86 \%$ market share

- Has strong heritage and loyal customer base

\section{Substitutes}

- In Luzon, Good Boy has a strong and unique taste that is hard to replicate

- In VisMin, specific dishes are made with Good Boy's products 


\subsection{SWOT Analysis}

\section{Strengths}

- Good Boy brand's Sliced Cheese has $86 \%$ market share

- Good Boy brand and SFI are currently in a strong financial position

- Good Boy's products are aligned with SFI's core competency of producing, distributing and marketing protein-rich products.

- Good Boy's will benefit from synergies with SFI's operations (e.g. warehousing, distribution, sales force, etc).

- Economies of scale will be in play in the common materials currently being bought by SFI.

\section{Opportunities}

- SFI will be in the position to utilize its experience in Marketing to further grow the Good Boy's brand.

- SFI can enter more categories using the Good Boy's brand name.

- SFI can leverage on the demand of Good Boy's Cheese by bundling its products together.

- There can also be cost synergies in terms of supply chain, manufacturing, distribution and marketing.

\section{Weakness}

- Good Boy brand's Sliced Cheese is seen as an old category especially by Gen Z and Gen Ys.

- Good Boy brand's sizes in Cheese Spread and Cheese Dip are still very small compared to the size of its sliced cheese.

\section{Threats}

- There is a minor threat of other competitors coming up with a Me-Too product but SFI believes this is a remote possibility given the strength of the Good Boy's brand and the size of prize for the competitors. 


\subsection{Financial Statement Analysis}

\subsubsection{Revenue Growth}

The Revenue growth rates indicate a healthy increase in sales from 2014 to 2016, with a total compounded annual growth rate of $11 \%$ (see Table 6). Under the Philippine setting, this growth rate is deemed healthy since this is roughly twice the annual GDP growth rate. Slower growth rate can be seen in the Cheese Spread product group, and therefore added attention should be given to this product line.

Table 5. Revenue Growth Rates

\begin{tabular}{llll} 
Product & $\mathbf{2 0 1 5}$ & $\mathbf{2 0 1 6}$ & CAGR \\
\hline Sliced Cheese & $10 \%$ & $13 \%$ & $11 \%$ \\
Cheese Spread & $5 \%$ & $6 \%$ & $5 \%$ \\
Cheese Dips & $12 \%$ & $10 \%$ & $11 \%$ \\
\hline Total & $10 \%$ & $12 \%$ & $11 \%$ \\
\hline
\end{tabular}

\subsubsection{Gross Profit Margin}

As shown in Table 4, gross profit margins were maintained at a 3year average of $52 \%$. This is an incredibly healthy GP rate for a canned food product, which usually has an average of 30\%. It shows the following positive qualities for the brand:

- Strong pricing power (maintain GP margins while being able to increase sales $11 \%$ annually).

- Manageable cost of materials and ingredients

- Stable cost of production

\subsubsection{Operating Expenses}

Operating Expenses (OPEX) as a \% of Sales is very stable at 24 25\% of Revenues. In the past 3 years, no major swings can be seen in the different OPEX types. The largest share of OPEX went to Marketing 
Expense at 52\% in 2014 (down to $45 \%$ in 2016), while smallest spend is on Admin Expense at $12 \%$.

Likewise, OPEX as a \% of GP is very healthy at $49 \%$ in 2016 . This is an important metric as it indicates how much of GP is spent on OPEX. This resulting figure of $49 \%$ simply means that the balance $51 \%$ goes to profit and tax which shows a healthy trend for the firm (see Table 6).

Table 6. Operating Expenses as a Percentage of Sales and Gross Profit

\begin{tabular}{lllllll} 
& 2014 & & 2015 & & 2016 & \\
& $\begin{array}{l}\text { \% of } \\
\text { Sales }\end{array}$ & $\begin{array}{l}\text { \% of } \\
\text { GP }\end{array}$ & $\begin{array}{l}\text { \% of } \\
\text { Sales }\end{array}$ & $\begin{array}{l}\text { \% of } \\
\text { GP }\end{array}$ & $\begin{array}{l}\text { \% of } \\
\text { Sales }\end{array}$ & $\begin{array}{l}\text { \% of } \\
\text { GP }\end{array}$ \\
\hline Marketing Expenses & $13 \%$ & $26 \%$ & $10 \%$ & $19 \%$ & $11 \%$ & $22 \%$ \\
Selling Expenses & $5 \%$ & $10 \%$ & $6 \%$ & $11 \%$ & $7 \%$ & $13 \%$ \\
$\begin{array}{l}\text { Distribution Expenses } \\
\text { Administrative Expenses }\end{array}$ & $4 \%$ & $8 \%$ & $5 \%$ & $8 \%$ & $4 \%$ & $8 \%$ \\
\hline Total & $25 \%$ & $50 \%$ & $24 \%$ & $44 \%$ & $25 \%$ & $49 \%$ \\
\hline
\end{tabular}

\subsubsection{Profit Margins and Profit Growth}

Profit Margins for the Good Boy's is strong at 18-21\% of Sales. The 2016 profit margins went down to 19\% due to lower GP\% and higher OPEX\% compared to prior year. This level of profitability is very healthy relative to the profit margins of SFI as can be seen in the Table 7.

Table 7. Profit Margins and Growth

\begin{tabular}{llll} 
& 2014 & 2015 & 2016 \\
\hline Net Profit After Tax & 558 Mil. P & 724 Mil. P & 740 Mil. P \\
NPAT\% & $18 \%$ & $21 \%$ & $19 \%$ \\
NPAT Growth & & $30 \%$ & $2 \%$ \\
\hline
\end{tabular}


Profit margins of Good Boy's is double that of SFI's. From a profit margin perspective, this acquisition will be accretive to SFI and will raise the latter's total profit margins (see Figure 1).

Figure 1. Good Boy’s vs. SFI Profit Margins

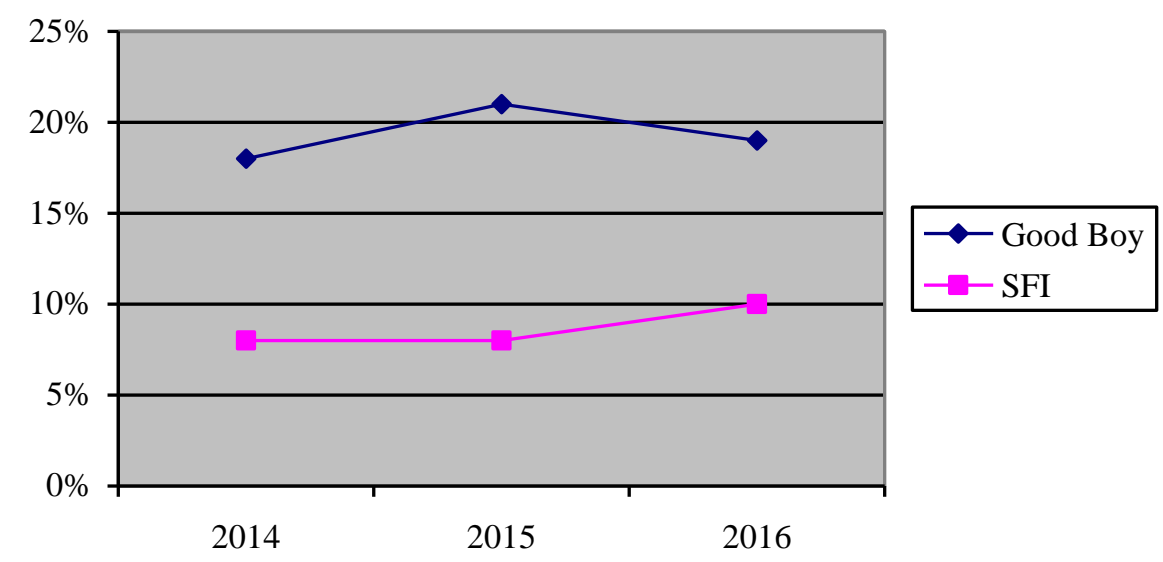

\subsection{Shareholder Value Analysis}

The Shareholder value analysis, a widely known approach in measuring the potential financial benefit of a major business decision (Mills \& Print, 1995), was used in analysing the acquisition of the Good Boy brand. To project the financials if SFI acquires the brand, a 5-year forecast was prepared (see Table 8) using the historical financials provided by IN-JAE (baseline), coupled with assumptions using conservative numbers:

- Lower figures of $10 \%$ revenue growth and 50\% GP margins were used year on year.

- OPEX of $25 \%$, which was the highest historical rate of IN-JAE, was also used.

- PE multiple method was used to compute for the Terminal Value. SFI's average PE multiple is 20-23x. To be conservative, lower multiple of 20x was used.

- SFI's Internal WACC is at $10 \%$, which was used as the discount factor in computing the NPV. 
Management Accounting Frontiers 3 (2020) 5 - 24

Table 8. Shareholder Value Analysis

\begin{tabular}{|c|c|c|c|c|c|c|c|c|}
\hline & $\begin{array}{l}\text { Actual } \\
2014 \\
\end{array}$ & 2015 & 2016 & $\begin{array}{l}\text { Forecast } \\
\text { Year } 1 \\
\end{array}$ & Year 2 & Year 3 & Year 4 & Year 5 \\
\hline Revenue & 3,186 & 3,504 & 3,913 & 4,304 & 4,734 & 5,207 & 5,728 & 6,301 \\
\hline Revenue \% & & $10 \%$ & $12 \%$ & $10 \%$ & $10 \%$ & $10 \%$ & $10 \%$ & $10 \%$ \\
\hline Gross Profit & 1,593 & 1,857 & 2,034 & 2,152 & 2,367 & 2,604 & 2,864 & 3,151 \\
\hline Gross Profit \% & $50 \%$ & $53 \%$ & $52 \%$ & $50 \%$ & $50 \%$ & $50 \%$ & $50 \%$ & $50 \%$ \\
\hline Total Operating Expenses & 796 & 823 & 977 & 1,076 & 1,184 & 1,302 & 1,432 & 1,575 \\
\hline OPEX \% & $25 \%$ & $24 \%$ & $25 \%$ & $25 \%$ & $25 \%$ & $25 \%$ & $25 \%$ & $25 \%$ \\
\hline Net Profit Before Tax & 797 & 1,034 & 1,057 & 1,076 & 1,183 & 1,302 & 1,432 & 1,576 \\
\hline Tax Expense & 239 & 310 & 317 & 323 & 355 & 391 & 430 & 473 \\
\hline Net Profit After Tax & 558 & 724 & 740 & 753 & 828 & 911 & 1,002 & 1,103 \\
\hline Depreciation and Amortisation & 80 & 80 & 80 & 80 & 80 & 80 & 80 & 80 \\
\hline EBITDA & 638 & 804 & 820 & 833 & 908 & 991 & 1,082 & 1,183 \\
\hline Net Working Capital & 319 & 421 & 430 & 516 & 568 & 625 & 687 & 756 \\
\hline NWC\% & $10 \%$ & $12 \%$ & $11 \%$ & $12 \%$ & $12 \%$ & $12 \%$ & $12 \%$ & $12 \%$ \\
\hline Increase in Net Working Capital & & & & 516 & 52 & 57 & 62 & 69 \\
\hline Free Cash Flow & & & & 317 & 856 & 934 & 1,020 & 1,114 \\
\hline Terminal Value & & & & & & & & 22,062 \\
\hline Net Cash Flow & & & & 317 & 856 & 934 & 1,020 & 23,176 \\
\hline Present Value & & & & 288 & 707 & 702 & 697 & 14,390 \\
\hline Net Present Value & & & & & & & & 16,784 \\
\hline
\end{tabular}


Resulting NPV of all Future Cash Flows is computed to be at 16.7 billion pesos. This means that 16.7 billion pesos is the expected future value of the brand to the shareholders.

Since the IN-JAE offer price is at $5 B$, this will be deducted from the NPV of all Future Cash Flows, which will result in an 11.7B NPV. This means shareholders will get this value despite subtracting the purchase price to be paid to IN-JAE.

The Internal Rate of Return is also computed at $44 \%$, which is way higher compared to SFI's WACC of $10 \%$. This means that this investment would yield higher returns compared to the internal cost of capital of the business.

\section{Conclusion}

This section summarises the research problem and the procedures adopted in evaluating the brand value and the rate of return for the firm that seeks to acquire the Good Boy brand. This section then concludes with the recommendations to the management of the SFI company. Though prior SCM literature supports for the relevance of the discipline to diverse functions such as design, purchases, manufacturing, and marketing (Shank \& Govindarajan, 2004), the evidence in relation to the marketing function has thus far been limited to product pricing and customer profitability analyses (Datar \& Rajan, 2018). This paper offers a participant-observed case study evidence on the relevance of SCM principles to assessing the value of brand acquisition. Combining strategic positioning models such as Porter's five-forces model and SWOT analysis with shareholder value analysis, this paper identifies the positive value likely to be generated when the firm SFI acquires the Good Boy brand from another firm IN-JAE. The findings of the study suggest the following:

- Good Boy is a well-known brand in the Philippines and dominates the sliced cheese market. The product brands fit well with SFI's other product lines. There are no foreseeable conflicts of interest or weaknesses of the brand.

- SFI has a long-term ambition of doubling every 5 years. Entry into the cheese segment via the Good Boy brand acquisition expands SFI's portfolio into adjacent categories, beyond its core businesses of protein-rich food. A broader product portfolio catering to different 
tastes and needs capture a larger customer base. This also entails a diversification of risk and input price exposures. Also, this acquisition is an opportunity to extract a number of potential synergies, thus lowering production costs.

- The Good Boy brand has healthy financials, good pricing power, and is accretive to the total SFI in terms of profit margins.

- Acquiring the Good Boy brand at 5 billion pesos will result to a net benefit of 11.7 billion pesos to the shareholders and IRR of $44 \%$ which is superior to the company's WACC of $10 \%$.

- All factors considered, this study recommends the SFI management to accept IN-JAE's offer and acquire the license for the Good Boy brand and its manufacturing equipment at 5 billion pesos. 


\section{References}

Anderson, S. W., (2006), "Managing Costs and Cost Structure throughout the Value Chain: Research on Strategic Cost Management", in C. Chapman, A. G. Hopwood, and M. D. Shields (ed.), Handbooks of Management Accounting Research, Vol. 2, Elsevier, Amsterdam, pp. 481-506.

Balmer, J. M. T. and Greyser, S. A., (2003), Revealing the Corporation: Perspectives on Identity, Image, Reputation, Corporate Branding, and Corporate-Level Marketing, Routledge, London.

Bahadir, S. C., Bharadwaj, S. G. and Srivastava, R. K., (2008), "Financial Value of Brands in Mergers and Acquisitions: Is Value in the Eye of the Beholder?", Journal of Marketing, Vol. 72 No. 6, pp. 49-64.

Basu, K., (2006), "Merging Brands after Mergers", California Management Review, Vol. 48 No. 4, pp. 28-40.

Bierman, H. and Smidt, S., (1993), The Capital Budgeting Decision, Prentice-Hall, Upper Saddle River.

Datar, S. M. and Rajan, M. N., (2018), Horngren's Cost Accounting. A Managerial Emphasis, 16th edn., Pearson Education, Harlow.

Foster, G., and Gupta, M., (1994), "Marketing, Cost Management and Management Accounting", Journal of Management Accounting Research, Vol. 6, pp. 43-77.

Guilding, C., Cravens, K. S. and Tayles, M., (2000), “An International Comparison of Strategic Management Accounting Practices", Management Accounting Research, Vol. 11 No. 1, pp. 113-135.

Guzmán, F., Iglesias, O., Machado, J. C., Vacas-de-Carvalho, L., Costa, P. and Lencastre, P., (2012), "Brand Mergers: Examining Consumers' Responses to Name and Logo Design", Journal of Product \& Brand Management, Vol. 21 No. 6, pp. 418-427

Mills, R. and Print, C., (1995), "Strategic Value Analysis: Shareholder Value and Economic Value Added - What's the Difference", Management Accounting, Vol. 73, No. 2, pp. 35-37.

Porter, M.E. (2008), "The Five Competitive Forces That Shape Strategy", Harvard Business Review, Vol. 86, No. 1, pp. 86-104.

Shank, J., and Govindarajan, V., (2004), Strategic Cost Management: The Value Chain Perspective, The Free Press, New York. 
Sinclair, R. and Keller, K. L., (2017), "Brand Value, Accounting Standards, and Mergers and Acquisitions: The Moribund Effect", Journal of Brand Management, Vol. 24 No. 2, pp. 178-192.

Van Raaij, E. M., (2005), "The Strategic Value of Customer Profitability Analysis", Marketing Intelligence and Planning, Vol. 23 No. 4, pp. 372381. 
Management Accounting Frontiers 3 (2020) 5 - 24 